\title{
ПРАГМАТИЧНИЙ АСПЕКТ МОВЛЕННСВОЇ ПОВЕДІНКИ ВЕДУЧИХ АМЕРИКАНСЬКИХ ТЕЛЕШОУ
}

\begin{abstract}
Анотація. У статті досліджуеться явище прагматичного впливу мовленневої поведінки. Описана поява та тлумачення терміну прагматики як науки, а також об'єкту їі дослідження на сьогоднішній день. Більше того, у статті міститься опис поняття мовленнєвої поведінки, їі характеристика та фрактори, від яких залежать особливості мовленневої поведінки з позицій соціолінгвістики. Також досліджено прагматичний вплив мовленневої поведінки ведучих американських телевізійних шоу, до того ж проаналізовано стратегії та тактики, які використовуються при здійсненні прагматичного впливу на глядачів та слухачів. Особливості прагматичного аспекту мовленневої поведінки ведучих американських телевізійних шоу проілюстровано на конкретних прикладах.
\end{abstract}

Ключові слова: прагматика, прагматичний вплив, прагматичний аспект, мовленнева поведінка, комунікативні стратегії, ведучі телешоу.

Tkachyk Olena, Khomenko Anastasiia National Technical University of Ukraine «Igor Sikorsky Kyiv Polytechnic Institute»

\section{PRAGMATIC ASPECT OF AMERICAN TV SHOWS' HOSTS' SPEECH BEHAVIOUR}

Summary. This article investigates the phenomenon of pragmatics, pragmatic influence and speech behavior. It is also told in the article that there should be seen the distinction between such notions as semantics and pragmatics. The emergence of the term "pragmatics" is described here. Also, in the article you may find the modern division of pragmatics that exists nowadays. The notion of pragmatic aspect is analyzed in the article, as well. The article also includes the description of the notion "speech behavior", its characteristics and factors, which influence speech behavior. It was investigated that there are factors like aspect of human's life; these are social, biological and psychological. Furthermore, it is indicated that the science which studies speech behavior is called sociolinguistics. It was found out that scientist were looking for the correct definition for the notion of speech behavior for a long time. Pragmatic influences of the speech behavior, description of the notion "TV show" were investigated, as well as strategies and tactics that are used with the intention of pragmatic influence of speech behavior from the speaker to the viewers or listeners. There is no particular division in the tactics, different scientists divide them differently. What is more, the peculiarities of the pragmatic aspect of American TV Shows' hosts' speech behavior were analyzed with the help of the specific examples. For analyzing the speech behavior were taken such TV show hosts as Ellen Degeneres, James Corden, Jimmy Kimmel and Jimmy Fallon. Mostly it was noticed that they use jokes in their speeches and also some phrases which motivate their viewers and listeners to some kind of action. It was noticed that the hosts of TV shows must be kind, friendly and outgoing. The thing that was investigated while analyzing the pragmatic influence of the speech behavior of the hosts that jokes are a good strategy to grasp audience's behavior, as well as to make the viewers and listeners relaxed, so that there is no tension. It was also noticed that the attention of host is usually concentrated on the guest who has come to the studio, rather than on the audience there.

Keywords: pragmatics, pragmatic influence, pragmatic aspect, speech behavior, communicational strategies, TV shows' hosts.

$\Pi$ остановка проблеми. Усім нам добре відомо, що телебачення та Інтернет мають великий вплив на нашу свідомість. Саме тому вчених-лінгвістів особливо цікавить той аспект прагматичного впливу, який досліджуе сереру мас медіа, особливо мовленнєва поведінка осіб, яких ми бачимо на екрані. В наші дні спостерігаеться зацікавленість людей, а особливо підлітків, в американських фільмах, серіалах та телешоу. Таким чином, наше дослідження лежить в рамках суспільного та наукового інтересу і спрямоване на аналіз мовленневої поведінки ведучих американських телешоу 3 метою встановлення прагматичного впливу, який вони прагнуть справити на глядачів та слухачів.

Аналіз останніх досліджень і публікацій. Серед проаналізованих наукових робіт у сфері прагматики та прагматичного впливу варто виокремити дослідження Н.Д. Арутюнової та Фло- рія Бацевича. У праці С. Аристова описані стратегії і тактики мовленнєвої поведінки. Вчений C. Срьоменко подає опис напрямів досліджень мовної особистості у сучасній лінгвістиці. У своїй монографії Томаш Врабель розкривае питання словотворчої прагматики англійської мови. Прагматичний вплив у сфрері мас-медіа досліджувався такими лінгвістами як Градова M.I., Арутюнова Н.Д., Ороховська Л.А та багатьма іншими.

Виділення не вирішених раніше частин загальної проблеми. Не дивлячись на широке висвітлення питання прагматичного впливу, в тому числі у сфері мас-медіа, залишається недостатньо розкритим питання прагматичного впливу ведучих сучасних телешоу.

Мета статті. Метою статті є дослідження прагматичного аспекту мовленневої поведінки ведучих американських телевізійних шоу, що допоможе на конкретних прикладах глибше зро- 
зуміти сучасну специфріку засобів прагматичного впливу мас-медіа на аудиторію.

Викладення основного матеріалу. Термін «прагматика», згідно з лінгвістичним енциклопедичним словником [3], використовуеться задля позначення сфери досліджень у семіотиці та мовознавстві, яка вивчає фрункціонування мовних знаків у мовленні. Введений термін був наприкінці 30-х рр. 20 ст. фрілосодром Ч.У. Морісом $[3 ; 15]$ у вигляді назви одного із розділів семіотики. Вчений розділив прагматику на семантику, яка вивчає відношення знаків до об'єктів, синтактику, тобто розділ про міжзнакові відношення, та прагматику, що досліджуе відношення мовців до знаків. Прагматика загострила увагу лінгвістів на великій кількості проблем, які мали довгу історію вивчення в межах риторики та стилістики, комунікативного синтаксису, теорії і типології мовлення та мовленнєвої діяльності, теорії комунікацї та фрункціональних стилів, соціолінгвістики, психолінгвістики, теорії дискурсу $[2 ; 3]$.

Сучасну прагматику також можна поділити на: мікропрагматику, макропрагматику та мегапрагматику. Мікропрагматика - це прагматика мовних одиниць, у межах якої досліджують суб'єктивний чинник, що наявний у семантико-прагматичній структурі лексичних і граматичних одиниць, а зокрема дискурсивних слів; суб'єктивні аспекти редеренції, дейксису, анафори та деякі інші проблеми. Макропрагматика, або ж прагматика категорій мовного коду в спілкуванні, досліджує суб'єктивний чинник, який пов'язаний 3 мовленневими актами, мовленневими жанрами та дискурсами, імплікаціями та імплікатурами, пресупозиціями, модальністю, умовами успішності категорій мовного коду тощо. Мегапрагматика - це прагматика категорій міжособистісної інтеракції, яка має справу з прагматичними аспектами інтенціональності, стратегій і тактик спілкування; прагматичними аспектами комунікативної компетенції учасників спілкування; категоріями з виразним виявом суб'єктивності: поглядом, емпатією та її фокусом; прагматичними аспектами принципів і максим спілкування, а також з прагматичними виявами риторичних чинників комунікації [6].

Поміж питань, які відносяться до прагматичного напряму дослідження мови, важливо окремо відзначити вивчення тексту в динаміці та його співвіднесеність з автором. Незважаючи на відносність та дискусійний характер прагматичного компонента, розрізняють два типи цього явища: часткова текстова прагматика, тобто прагматика продуцента, що здійснюеться в горизонтальній площині мовлення; і повна текстова прагматика - прагматика реципієнта, що є результатом прочитання всього тексту.

Відповідно до умов комунікації, слово, яке виникає у свідомості комунікантів, набуває певного суспільно-соціального значення, не завжди прямо й безпосередньо пов'язаного 3 його номінативним значенням. За таких умов свого значення набуває залежність між значенням слова, ситуацією іменування, соціальними стосунками автора та спостерігача. Останній із цих чинників виступає у якості основи для формування прагматичних конотацій [8].
Прагматичний аспект викликає плутанину через те, що між конотативним та прагматичним аспектами значення важко провести чітку межу. Вагомий внесок у виділення суто прагматичних аспектів дослідження мовних одиниць та категорій здійснив Флорій Бацевич, обгрунтувавши власну наукову позищію наступним чином: «Основою формування прагматичних аспектів (складників, елементів) одиниць i категорій різних рівнів мови є суб'єктивне ставлення людей (груп людей, етносів) до певних об'єктів (у широкому розумінні слова) дійсності і одиниць, які їх позначають» $[4$, с. 81]. Він підкреслював, що люди, які використовують у процесі лінгвістичної комунікації мовні знаки, не ставляться до них байдуже - вони по-різному реагують на ті чи інші мовні одиниці, а через них - і власне на самі денотати.

Щодо мовленневої поведінки, то загалом мовленневою поведінкою називають емоџї, дії, вчинки людини, які передаються за допомогою мовлення та невербальних засобів [12]. Насамперед мовленнева поведінка охоплюе три взаємопов'язаних аспекти діяльності людини: соціальний, психологічний і біологічний [13].

Мовленнєву поведінку учасників спілкування, процеси породження ними оптимальних варіантів побудови соціально коректних повідомлень, вияв соціальних норм, які детермінують мовленнєву поведінку учасників спілкування, механізми формування білінгвізму тощо, досліджує така наука як соціолінгвістика [5].

Для того, щоб охарактеризувати мовленневу поведінку, часто використовуеться словосполучення «мовленнєва діяльність». Мовленнєву діяльність визначають як процес використання людиною мови з метою передачі і засвоєння суспільно-історичного досвіду, встановлення комунікації або планування своїх дій [11].

I. Зимняя подає ще одне значення мовленнєвої діяльності: «Мовленнева діяльність - це процес активного, цілеспрямованого, мотивованого, опосередкованого мовою і зумовленого ситуацією спілкування взаємодії людей між собою, спрямованої 17 на задоволення комунікативно-пізнавальної потреби людини у процесі спілкування» [10, c. $28-29]$.

Не менш важливо згадати, що комунікативні стратегії і тактики представляються основними засобами маніпулювання і досягнення бажаних цілей. Під комунікативною стратегією розуміється планована магістральна, довгострокова лінія мовної поведінки, обрана комунікантом для досягнення основної мети у взаємодії. Комунікативна стратегія реалізуеться за допомогою ряду комунікативних тактик, тобто сукупностей практичних ходів у процесі мовленневої взаємодії [2].

Досить довгий період часу дослідники і лінгвісти шукали чітке визначення терміну мовленнєва поведінка. Це поняття не зникало із сфрери лінгвістичних досліджень протягом усього ХX століття, при цьому було широко застосованим - від випадкового, епізодичного до глобального, із поняттям «мова як є». Унаслідок чого, різні дослідники вклали найрізноманітніший зміст у це поняття. Представлення поняття «мовленнева поведінка" має грунтуватись на самому фракті мовлення, так само як і на відборі мовних засобів, які дескриптивна лексика, на жаль, не 
прагне брати до уваги. Т.Г. Винокур обгрунтовуе полісемічність терміну «мовна поведінка» і «мовленнєва поведінка", підкреслюючи, що "мовна поведінка" показувала загальнотеоретичні погляди таких науковців як Л.В. Щерба, Б.Д. Поліванов, Л.П. Якубінський і вказувала на глобальний масштаб застосування цього френомену. До того ж, мовною поведінкою називали поведінку загалом і вона формулювалась як уся сукупність елементів життедіяльності людини, тобто як соціально-психологічна сутність. Поняття «мовленнева поведінка" почали використовувати згодом гуманітарні науки: антропологія, сощіологія, психологія, психолінгвістика, внаслідок чого з'явились такі поняття як «діяльність", «комунікація».

Мовлення у конкретній ситуації називають мовленнєвою поведінкою. Вона передбачає усвідомлення людиною особливостей даної ситуації і своєї ролі в ній. Кожна людина діє в рамках своєї волі. Мовленнєва поведінка формується в залежності від ролі. Також, мовленнева поведінка демонструе культурний і освітній рівень людини, що зводиться до необхідності підбору слів за стилем, складністю, типом інтонації, тембром, способом побудови речень, разом з мімікою і жестами. Правильне застосування мовлення згідно 3 ситуащією свідчить про високий рівень розвитку особистості, належне володіння нормами поведінки у суспільстві [9].

Кожен тип мовленневої поведінки корелює з певним аспектом прагматичного змісту.

Прагматичний вплив мовця проявляеться у мовленнєвій поведінці через реалізацію відповідних комунікативних стратегій і тактик.

Комунікативна стратегія - це комплекс певних мовленневих дій, спрямованих на досягнення комунікативної мети. Незважаючи на значну кількість досліджень у цій царині, певної єдиної класифрікації стратегій спілкування дотепер не існує.

Одні дослідники, зокрема і Т. ван Дейк, виокремлюють такі стратегії спілкування, як контекстуальні, мовленнєві, семантичні, синтаксичні, схематичні, текстові. Інші вчені виділяють власне комунікативну (правила й послідовність комунікативних дій, які виконуе мовець) і змістову (поетапне змістове планування мети з урахуванням наявного мовного коду в межах кожного ходу в комунікації) або ж можна виділити кооперативні (інформативні й інтерпретативні діалоги, сюди відносяться поради, розповіді, повідомлення) та некооперативні (такі як конфлікти, суперечки, претензії, погрози, ухиляння від відповіді) комунікативні стратегії.

При спілкуванні дуже важливо вміти розпізнати психологічну позицію партнера i обрати для себе таку, що зможе забезпечити конструктивне розв'язання питання. У зв'язку з цим виділяють маніпулювання як одну зі стратегій прагматичного впливу.

Маніпулювання - це різновид прихованого психологічного впливу на психічні структури людської особистості з метою одержання бажаного для маніпулятора результату. Часто ці маніпуляції можуть відбуватись на підсвідомому рівні.

Маніпулювання полягае в подвійному впливі: разом з адресованим реципіентові відкритим повідомленням маніпулятор надсилає йому "за- кодований" сигнал, сподіваючись на те, що цей сигнал активізуе в свідомості адресата потрібні для маніпулятора образи.

Стратегія, що обирається учасниками спілкування в тій чи іншій комунікативній ситуації, передбачає застосування відповідної комунікативної тактики, тобто визначеної лінії поведінки на певному етапі комунікативної взаємодії, що спрямована на отримання очікуваного результату або ж запобігання небажаного. Комунікативна тактика - це спосіб втілення стратегії мовленнєвої поведінки, який передбачає виконання однієї або ж декількох дій, які сприяють реалізації стратегії [14].

Зазвичай за допомогою мовленневої поведінки мовець намагається переконати слухачів у правдивості своїх слів та доказів. А деякі з мовленневих актів ціленаправлені на переконання слухача виконати певну дію. Мовець викликає власною мовленнєвою дією акт-відповідь слухача [7].

3 ім'ям Ю.М. Караулова пов'язаний початок різнопланового дослідження поняття «мовної особистості». Під ловною особистістю він передбачає «сукупність здібностей і характеристик людини, які обумовлюють створення та сприйняття нею мовленнєвих творів (тобто текстів), що різняться ступенем структурно-мовної складності; глибиною та точністю відображення дійсності; певним цільовим спрямуванням». Тотожне розуміння мовної особистості спостерігаємо й у поглядах Ф.С. Бацевича, який визначає мовну особистість як «індивіда, що володіє сукупністю здатностей і характеристик, які зумовлюють створення й сприйняття ним текстів, що вирізняються рівнем структурно-мовної складності та глибиною й точністю відображення дійсності» [9, с. 33-37].

Через мовленнєву поведінку можна легко здійснювати прагматичний вплив, адже правильно підібрані слова та мовленнева стратегія можуть допомогти при впливі на публіку. Особливо чітко це проглядається на прикладі ведучих американських телешоу.

Термін «телевізійне шоу» традищійно асощіюеться з контролем ведучого за обговоренням певного питання поміж гостями та ведучим або певними експертами в студії, з міжособистісною розмовою, витоки якої сягають традищій усного мовлення. Комунікативно-прагматичні особливості англомовного телевізійного дискурсу телевізійних шоу включають тріадичну структуру «інтерв'юер інтерв'юйований - телевізійна аудиторія».

Для аналізу прагматичного впливу ведучих американських телешоу на глядачів та гостей було обрано такі шоу, як "The Late Late Show", "Ellen Show", "Jimmy Kimmel Live" та "The Tonight Show Starring Jimmy Fallon".

У зазначених телешоу ведучими використовувалися такі комунікативні тактики як гумор, спонукання до дії та заохочення.

Для прикладу спонукання до дії та заохочення, візьмемо висловлювання Джеймса Кордена в телевізійному шоу під назвою "The Late Late Show": "We'll be chatting with Regina Hall, then we got the performance from Moby, you don't want to miss that", що можна перекласти як: "Mu cniлкуватилелося з Реджиною Холл, а потіл для нас виступатиле Мобі, ви не хочете ие про- 
nустити». Отож, Джеймс закликає глядачів приеднатися до перегляду, частково заохочуючи фрразою "...ви не хочете ие пропустити". Дана фрраза являється певним викликом для глядачів, а особливо для підлітків. В даному випадку також важливо правильно передати мовленнєву поведінку ведучого при перекладі, адже таким чином буде перенесений прагматичний аспект, який закладався в мові оригіналу.

Також для прикладу тактики 3 використанням гумору можна привести слова Еллен Дедженерес, в телевізійному шоу, яке носить назву "Ellen Show", які вона сказала актору Майклу Б. Джордану: "I can see you let yourself go", що можна передати українською мовою як: "Тож я бачу, ти запустив себен, де мається на увазі фрізична форма. Але це був жарт, спрямований на те, щоб зняти напругу в залі і щоб усі почувались комфортно. Загалом, Еллен часто використовуе гумор та жарти у своїх висловлюваннях з різною метою - або щоб зняти напругу, або для сощіальної комунікації та прагматичного впливу.

Не менш цікавим для аналізу виявився Джиммі Кіммел та його шоу “Jimmy Kimmel Live". Взяти для прикладу такі його слова: "Please say hello to Steve Harvey”, що перекладається як «Будь лас$\kappa a$, привітайте Стіва Харві». У даному випадку можна спостерігати спонукання глядачів до певної дії, у цій ситуації - до аплодування та вигуків.

I звісно ж, неможливо оминути таке телевізійне шоу, як "The Tonight Show Starring Jimmy Fallon" та його незмінного ведучого Джиммі Феллона. Так, як Джиммі комік, то звісно ж у своїх шоу він використовуе багато жартів для того, щоб зняти напругу та для впливу і сощіальної комунікації, як і у випадку з Еллен Дедженерес. Для аналізу було вибрано такі його слова: “That's right, the subways are once again running 24 hours a day, minus the 23 hours they're out of service, but still”, що можна перекласти наступним чином: "Сале так, метро знову працюе иілодобово, мінус 23 години, коли воно не працює, але все ж». На що глядачі в залі відреагували гучним сміхом та оплесками.

Доволі часто, саме мовленнєва поведінка, яка підсилена жартами додає більшої зосередженості глядачів та слухачів до мовця, оскільки важко сприймати монотонний потік слів. Американські телевізійні ведучі досить часто вдаються до жартів зі своїми гостями та глядачами із залу. Не рідко на американських телевізійних шоу прагматичний вплив спрямований саме на гостя, а не на глядачів.

Важливо також зазначити, що для кращого прагматичного впливу мовленнєвої поведінки, ведучим часто потрібно бути привітними, чесними та відкритими. Навряд чи хтось захоче дивитися телевізійне шоу для того, щоб побачити там насупленого ведучого.

Висновки i пропозиції. Отже, прагматичний аспект мовленнєвої поведінки ведучих телевізійних шоу є актуальним і цікавим для вивчення. Прагматичний вплив в умовах сучасного світу здійснюеться з урахуванням онлайн фрормату, що дозволяе маніпулювати людьми через певні підібрані стратегії і тактики мовленнєвої поведінки.

Щодо ведучих американських телешоу, то найчастіше вони використовують спонукання до певної дії або ж впроваджують гумор та жарти у свої промови для того, щоб заволодіти увагою глядачів, зняти напруження. Також жарти використовуються для соціальної комунікації та впливу.

Перспективним $є$ дослідження порівняння стратегій і тактик, які у своїй мовленневій поведінці використовують ведучі американських та британських телевізійних шоу. Можна буде помітити відмінність через їх ментальність, національні традиції та особливості культури.

\section{Список літератури:}

1. Аристов С. Ситуированная модель смены коммуникативных ролей. URL: http://studydoc.ru/doc/4091054/ situirovannaya-model._-smenykommunikativnyh-rolej

2. Арутюнова Н.Д., Падучева Е.В. Истоки, проблемы и категории прагматики. Вступительная статья // Новое в зарубежной лингвистике. Москва : Прогресс. 1985. Вып. XVI. Лингвистическая прагматика. С. 3-43.

3. Арутюнова Н. Д. Прагматика // Языкознание. Большой энциклопедический словарь / Гл. ред. В.Н. Ярцева. 2-е изд. Москва : Большая Российская энциклопедия, 2000. С. 389-390.

4. Бацевич Ф.С. Вступ до лінгвістичної прагматики : підручник. Київ : ВЦ «Академія», 2011. 304 с. (Серія «Альмаматер»).

5. Бацевич Ф. С. Основи комунікативної лінгвістики : підручник. Київ : Академія, 2004. 342 с. (Альма-матер).

6. Бацевич Ф.С. Природність спілкування як лінгвопрагматична категорія. Мовознавство. 2011. № 1. С. 3-12. URL: http://nbuv.gov.ua/UJRN/MoZn_2011_1_3

7. Врабель Т. Словотворча прагматика у сучасній англійській мові. Берегове - Ужгород : ЗУІ ім. Ф. Ракоці II TOB «РIК-У», 2020.

8. Градова M.I. Прагматичний аспект одиниці номінації у художньому тексті. URL: http://www.rusnauka.com/ 4._SVMN_2007/Philologia/19899.doc.htm

9. Срьоменко С. Напрями досліджень мовної особистості у сучасній лінгвістиці. Записки з романо-герланськоі фбілології. 2014. Вип. 2(33). С. 33-37.

10. Зимняя И. Психологические аспекты обучения говорению на иностранном языке. Москва, 1978. 159 с., с. $28-29$.

11. Леонтьев А. Язык, речь, речевая деятельность. Москва, 1969. 212 с., 26 ст.

12. Мацько Л.І., Кравець Л.В. Культура української фрахової мови : навч. посіб. Київ : ВЦ «Академія», 2007. 360 с. (Альма-матер).

13. МОВА І КУЛЬТУРА. (Науковий журнал). Київ : Видавничий дім Дмитра Бураго, 2014. Вип. 17. Т. VII (175). 560 с.

14. Тележкіна О.О., Лисенко Н.О., Кушнір О.О. Ділове спілкування: усна і писемна форми : навчальний посібник. Харків : Смугаста типографрія, 2015. $384 \mathrm{c.}$

15. Morris C. IV. Writings on the general theory of signs. The Hague, 1971.

\section{References:}

1. Aristov S. Situirovannaja model' smeny kommunikativnyh rolej [Situated model of changing communicative roles]. Available at: http://studydoc.ru/doc/4091054/situirovannaya-model._-smenykommunikativnyh-rolej (accessed 26 May 2021). 
2. Arutjunova N.D., Paducheva E.V. (1985) Istoki, problemy i kategorii pragmatiki [Origins, problems and categories of pragmatics]. Novoe $v$ zarubezhnoj lingvistike [New in foreign linguistics]. Moscow: Progress, pp. 3-43.

3. Arutjunova N.D. (2000) Pragmatika // Jazykoznanie. Bolshoj enciklopedicheskij slovar [Pragmatics // Lingustics. Big encyclopedic dictionary]. Bolshaja Rossijskaja enciklopedija [Big Russian encyclopedia]. Moscow, pp. 389-390.

4. Bacevych F.S. (2011) Vstup do lingvistychnoyi pragmatyky [Introduction to linguistic pragmatics]. Kyiv: Akademiya. (in Ukrainian)

5. Bacevych F.S. (2004) Osnovy komunikatyvnoyi lingvistyky [Fundamentals of communicative linguistics]. Kyiv: Akademiya. (in Ukrainian)

6. Bacevych F.S. (2011) Pryrodnist spilkuvannya yak lingvopragmatychna kategoriya [Naturalness of communication as linguopragmatic category]. Movoznavstvo [Linguistics], no. 1, pp. 3-12. Available at: http://nbuv.gov.ua/UJRN/ MoZn_2011_1_3 (accessed 26 May 2021).

7. Vrabel T. (2020) Slovotvorcha pragmatyka u suchasnij angliyskij movi [Word-forming pragmatics in modern English language]. Beregove - Uzhgorod: ZUI im. F.Rakoci II - TOV «RIK-U».

8. Gradova M. I. Pragmatychnyj aspekt odynyci nominaciyi u xudozhnomu teksti [Pragmatic aspect of the unit of nomination in a literary text]. Available at: http://www.rusnauka.com/4._SVMN_2007/Philologia/19899.doc.htm (accessed 26 May 2021).

9. Yeromenko S. (2014) Napryamy doslidzhen movnoyi osobystosti u suchasnij lingvistyci. Zapysky z romanogermanskoyi filologiyi [Directions of research of language personality in modern linguistics. Notes on RomanoGermanic philology], pp. 33-37.

10. Zimnjaja I. (1978) Psihologicheskie aspekty obuchenija govoreniju na inostrannom jazyke [Psychological aspects of teaching to speak a foreign language]. Moscow, p. 159. (in Russian)

11. Leontev A. (1969) Jazyk, rech, rechevaja dejatelnost [Language, speech, speech activity]. Moscow, p. 212. (in Russian)

12. Maczko L.I., Kravecz L.V. (2007) Kultura ukrayinskoyi faxovoyi movy [Culture of the Ukrainian professional language]. Kyiv: Akademiya, p. 360. (in Unkrainian)

13. Mova i kultura (2014) [Language and culture]. Kyiv: Vydavnychyj dim Dmytra Burago, p. 560.

14. Tyelyezhkina O.O., Lysenko N.O., Kushnir O.O. (2015) Dilove spilkuvannya: usna i pysemna formy [Business communication: oral and written forms]. Kharkiv: Smugasta typografia. (in Ukrainian)

15. Morris C. (1971) IV. [Writings on the general theory of signs. The Hague]. 